\title{
Ayurvedic Management of Frozen Shoulder (Apabahuk)- A Case Report
}

\author{
Case Report
}

\section{Prakash Kumbar ${ }^{1 *}$, Lokesh Kumar Rajput², Garima Singh²}

1. Professor and HOD, 2. PG Scholar,

Department of Kayachikitsa, Parul Institute of Ayurved, Parul University, Vadodara.

\begin{abstract}
Background: Apabahuk is disease considered under vatavaydhi which can be compared with frozen shoulder considering similarity of signs and symptoms of disease. It is estimated that Between 16-26\% of shoulder pain cases are self-reported. It's the third commonest explanation for musculoskeletal consultation in medical care. Severely restricted movements of shoulder joint and progressive loss of both active and passive range of movements are the characteristics of frozen shoulder. In modern medicine several anti-inflammatory analgesics are getting used. Some major exercises advised and a few local applications of analgesic ointments is employed. But no such effective results found.Case: A53 year male patient consulted with complaints of pain and restricted painful movements of left shoulder joint associated with tremor, neck pain and reduced strength in the left-hand Conclusion: Patient was diagnosed as Apabahuk (frozen shoulder) and treated with panchakarma therapies and oral herbal medicines. The encouraging improvement was observed in both subjective and objective parameters.
\end{abstract}

Key Words: Apabahuk, Anti-inflammatory, Panchakarma.

\section{Introduction}

Apabahuka is a Vatavyadhi. It includes words, "Apa" and "Vahuka"(1). The very phrase 'Apa' means 'Viyoga' 'Vikrutau,' this means that disorder or separation. And the very phrase 'Vahuka' has the subsequent meaning: 'Vahu' means the limb, that's one of the sadanga's. According to Sanskrit literature, the phrase Apabahuka means horrific stiffness and muscle spasm in arm (2). It is an ailment as a result of kupita vata dosa localizing across the amsa pradesa, which reasons the shosana of amsa sandhi, leads to akunchana of sira on the site and giving rise to bahu-praspandana haratwam (3). It is an ailment that commonly have an effect on the amsa sandhi (shoulder joint). It may be taken into consideration because the initial stage, wherein loss or dryness of shleshaka kapha from amsa sandhi happens. The subsequent stage, that is, apabahuka happens because of the lack of shleshmka kapha and signs like amsashoola (shoulder ache) all through movements, restrained motion and so forth are manifested. Two varieties of pathophysiology have been defined for amsa shosha in classics. Those are suddha vatajanya (dhatukshaya janya) and vatakapaha janya(4). The symptoms of apabahuka like shoola, stabdata and bahupraspandan haratwam are equal as that of the signs of frozen shoulder.

\section{* Corresponding Author:}

\section{Prakash Kumbar}

Associate Professor and HOD,

Department of Kayachikitsa,

Parul Institute of Ayurveda,

Parul University, Limda. Vadodara, Gujarat. India.

Email Id: shriniwasdjadhav@gmail.com
Frozen shoulder affects patient aged 35 years to 70 years and it's estimated that $3 \%$ of individuals develop the disease over their lifetime. It is estimated that Between $16-26 \%$ of shoulder pain cases are selfreported. It's the third commonest explanation for musculoskeletal consultation in medical care. Males tend to be affected less frequently than female and there's predilection for race (5). In modern medicine several anti-inflammatory analgesics are getting used. Some major exercises advised and a few local applications of analgesic ointments is employed. But no such effective results found. It's also referred to as Adhesive Capsulitis. It's a painful and disabling disorder of shoulder capsule. It most ordinarily affects the people between the age of 40 to 60 and occurs in women more often than man. The animal tissue surrounding the glenohumeral joint of shoulder becomes inflamed and stiff, greatly restricting movement and causing chronic pain. Pain is typically constant, worse in the dark and with weather. Certain movement can provoke tremendous pain and cramping. Risk factors for frozen shoulder include tonic seizures, DM, stroke, accidents, lung disease, animal tissue disorder and heart condition. Severely restricted movements of shoulder joint and progressive loss of both active and passive range of movements are the characteristics of frozen shoulder (6). Here we are representing a case of frozen shoulder which was treated successfully with ayurvedic medicines and procedures.

\section{Case Report}

A 53 year male patient consulted in the outpatient department of the Parul Ayurved Hospital, Limda Vadodara with complaints of gradually progressive pain in the left shoulder joint with restricted 
movements for 6 months associated with tremor, reduced strength in the left hand and mild neck pain for 3 months.

\section{History of Present Illness}

A well-built, 53-year-old man was apparently healthy six months ago, employed as a driver in an export business who used to take a long drive as part of his job without getting a decent rest or sleep. Due to excess work load without sufficient resting time and irregular postures of sleep. He noticed mild pain in left shoulder joint but he ignored it. Later on, he felt difficulty in shoulder movement which restricted him to do his daily activities including his professional life. The pain was of gradual onset, nature of pain was dull aching and his sleep become disturbed. Initially he used to apply some ointments and takes some analgesics tablets which subsides the pain for some extent. But when he gets back to his routine activities pain reappears. It was worst at night and not able to sleep properly. Hence, he was referred to an orthopedician. He did his X-ray-shoulder joint (left), BSL(R), RA test. It was normal. He diagnosed the case as a frozen shoulder and prescribed analgesics and advised physiotherapy. After three-month, patient noticed further restriction of movements of shoulder joint, weakness of left hand, tremors and slightly reduced strength in left hand. For all these complaints, he consulted Parul Ayurved Hospital for Ayurvedic management. No history of chronic illness like diabetes, hypertension etc. And injury to shoulder joint. On examination, general condition was good, vitals- HR- 86/min, BP- 140/80 $\mathrm{mm}$ of $\mathrm{Hg}, \mathrm{CVS}-\mathrm{s} 2 \mathrm{~s} 2$ heard, no murmur, RS- bilateral air entry equal, no added sounds, no pallor and no icterus. Local examination of left shoulder joint findings was tenderness at anterior and posterior aspect of left shoulder joints $(+++)$ on palpation. On inspection no abnormalities were seen. Abduction and adduction were extremely painful, unable to raise hand above 25 degree, painful and restricted movement of joint. On the basis of above observation and history, we diagnosed case as Apabahuk (frozen shoulder) and patient was admitted in Parul Ayurved Hospital under Kayachikitsa department on 29/10/2021 with OPD/ IPD No. $20017681 / 201975$.

\section{Treatment}

Considering the involvement of dosha - dhatu, the treatment was planned as follows.

- On the day of admission (29/10/2021)

- Kostashodana was advised with Gandarvahastadi tail $30 \mathrm{ml}$ with $50 \mathrm{ml}$ of milk at night and 3 vegas were observed.

- Panchakarma treatment was started from 30/10/2021.

- Sarvanga Abhyanga with Sahacharadi Tail followed by bhaspa sweda

- Patra Pinda Sweda from cervical region to left upper limb

- Greeva Basti with Kottamchukadi Tail for 30 minutes.

- Matra Basti with Balaaswagandha Tail $40 \mathrm{ml}$ for 7 days.

- Oral medications:

- Rasnapanchak Kwatha - $15 \mathrm{ml}$ three times a day with equal quantity of warm water.

- Trayodashang guggulu - 2 tab two times a day with warm water.

- Eranda, Rasna, Nirgundi And Shunti Churna Kashaya $50 \mathrm{ml}$ two times a day (Moming at $7 \mathrm{am}$ and evening at $6 \mathrm{pm}$ ).

- Patient was discharged on $7 / 11 / 2021$ with the

following shamanoushadi.

- Tab. Trayodhashanga guggulu 2-0-2 with warm water for 21 days

- Syr. Rasnapanchak Kashaya 10-0-10ml with warm water for 21 days.

\section{Results}

The effect of treatment was assessed based on subjective and objective parameters. The subjective parameters include pain and stiffness (Scoring system as per opinion of Carolyn M Hicks 1999) (7), objective parameters include visual analogue scale for pain assessment and movements of the shoulder joint. Results were as follows.

Table 1: Subjective Parameters Assessment

\begin{tabular}{|c|c|c|c|c|}
\hline \multirow{2}{*}{ Parameters } & \multirow{2}{*}{ Findings } & \multirow{2}{*}{ Grading } & \multicolumn{2}{|c|}{ Findings } \\
\hline & & & BT 29/10/ 2020 & AT $07 / 11 / 2020$ \\
\hline \multirow{4}{*}{ Pain } & No pain & 0 & \multirow{4}{*}{3} & \multirow{4}{*}{1} \\
\hline & $\begin{array}{c}\text { Mild pain - particularly on moving the shoulder, able to continue } \\
\text { routine work with difficulty. }\end{array}$ & 1 & & \\
\hline & $\begin{array}{c}\text { Moderate Pain - pain felt on movement, at rest, interfering with } \\
\text { routine work. }\end{array}$ & 2 & & \\
\hline & $\begin{array}{c}\text { Severe Pain - felt on movement and also at rest, disturbing sleep } \\
\text { unable to carry out most of the routine work. }\end{array}$ & 3 & & \\
\hline \multirow{4}{*}{ Stiffness } & No stiffness & 0 & \multirow{4}{*}{3} & \multirow{4}{*}{1} \\
\hline & $\begin{array}{c}\text { Mild stiffness - particularly on moving the shoulder, able to continue } \\
\text { routine work with difficulty }\end{array}$ & 1 & & \\
\hline & $\begin{array}{c}\text { Moderate stiffness - pain felt on movement, at rest, interfering with } \\
\text { routine work }\end{array}$ & 2 & & \\
\hline & $\begin{array}{c}\text { Severe stiffness - felt on movement and also at rest, disturbing sleep } \\
\text { unable to carry out most of the routine work }\end{array}$ & 3 & & \\
\hline
\end{tabular}




\section{pain scale}

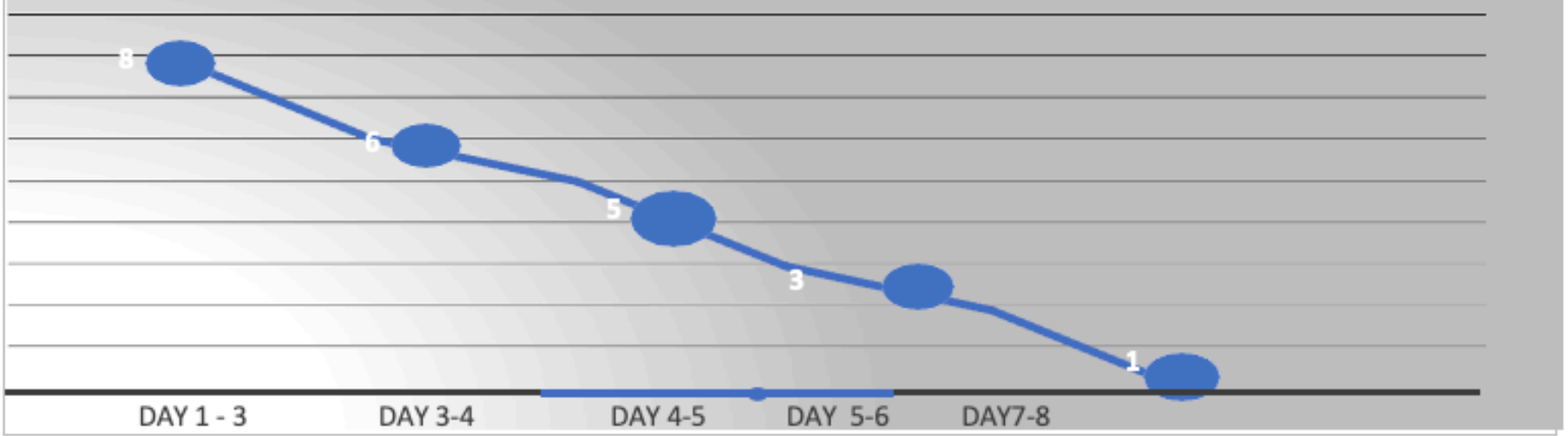

Table 2: Objective Parameters Assessment

\begin{tabular}{|c|c|c|}
\hline Criteria & BT & $(\text { AT })^{* *}$ \\
\hline Abduction $\left(0-170^{\circ}\right)$ & $65^{\circ}$ & $130^{\circ}$ \\
\hline Adduction in extension $\left(0-50^{\circ}\right)$ & $25^{\circ}$ & $35^{\circ}$ \\
\hline Forward flexion $\left(0-165^{\circ}\right)$ & $60^{\circ}$ & $130^{\circ}$ \\
\hline Backward extension $\left(0-60^{\circ}\right)$ & No backward extension & $50^{\circ}$ \\
\hline External rotation in extension $\left(0-70^{\circ}\right)$ & No external rotation & $55^{\circ}$ \\
\hline Intemal rotation in extension & Unable to move left hand in backward direction & Able to get the left hand behind the back \\
\hline
\end{tabular}

\section{Discussion}

Frozen shoulder is a disease of shoulder joint and is self-limiting, but recovery takes for much longer time up to 3-4 yrs. and it recovers in 3 steps. First step is freezing step which lasts for six weeks to six months. In this phase intensity of pain is extremely much and movement is gradually restricted. Second stage is named frozen stage. It lasts for 4 months to six months. In this stage pain intensity decreases but range of movement is lost. Shoulder becomes notably stiff which restricts active and passive movements of joint. Third stage lasts for about 6 months to 2-4 yrs. In this stage stiffness is gradually relived pain is extremely less as compared to previous 2 stages. This stage is typically well tolerated by patient as pain and stiffness both are gradually relieved. Many treatment options are available for management of frozen shoulder still there is no consensus in literature regarding which therapeutic option is superior mostly due to lack of high level of evidence ${ }^{8}$ because the recovery period is far longer and initial stage of freezing is extremely painful some alternative treatment like Ayurveda is very beneficial.

In Ayurveda, vatavyadhis are more in number among nanatmaja vyadhi, so,vayu might be called as the rotate of the cycle which conveying the life towards the limit. Frozen shoulder/adhesive capsulitis of western medication is conveying the comparable highlights of apabahuka of ayurvedic medication. So, in present study, frozen shoulder has been taken as a current relationship of apabahuka. The term initially found in susruta samhita (500 BC), later different acharyas like
Vagbhatta, Madhavakar, Sarangadhara and Bhavmisra have mentioned the term apabahuka in their separate samhitas. During survey of the samhitas and going through the induction it very well may be characterized as a disease caused by kupita vata dosa. Apabahuka is a disease of amsa-pradesh caused by kupita vata dosa which does the soshana of amsa sandhi, accordingly prompting akunchana of sira at that site and offering ascend to bahupraspandana haratwam. In consideration to the ayurvedic etiopathogenesis of the disease it uncovers that the vata prakopaka etiology in general is essentially liable for the beginning of the disease and similar etiological factors were observed in this case. The particular etiology like weight lifting, excessive hand movements, sahasa karma, dukkhashayya (mal resting posture) especially hand under the head during sleeping are the fundamental causative variables. Vitiated vata circulates all over the body (prasara) yet it happens uncommonly at the region of amsasandhi (sthanasamsraya) because of the earlier 'khavaigunya' and prompts dosa dusya sammurchana at the said place. The symptomology in ayurvedic science is soshana, sankochana and ruja which are additionally like the symptomatology like dryness, stiffens around the shoulder and pain referenced in contemporary science. The line of the treatment of contemporary science isn't so effective and promising. Physiotherapy, NSAIDS and local analgesics are used for the treatment of frozen shoulder in allopathy. In ayurveda, panchakarma and oral medications are explained for the treatment of vata predominant disease. 
Probable mode of drug action

\section{Trayodashanga guggulu}

Apabahuk is a vatavydhi, casused because of vitiation of vata and kapha dosha. Vata vriddi, kapha kshaya and involvement of pitta dosha produces signs and symptoms of apabahuk. For the disintegration of pathology of apabahuk, the drugs should pose few important qualities like vatadosha hara, dhatvagnivardhaka, dhatuposhak, vedanashamak and should have snigdha property as amsa sandhi is a place of kapha. The drug trayodashanga guggulu is a combination of thirteen herbal drugs together with guggulu processed in ghee. The components like shatavari, ashwagandha, and guduchi are called rejuvenators and affords energy to dhatus. Shunthi and ajamoda enhance jatharagni while babbul is specifically performing on asthidhatwagni. Ghee with its yogavahi guna allows in higher absorption and penetration of the drug. Thus, trayodashang guggulu at once affects at the etiology of apabahuk and allows withinside the disintegration of the samprapti and settles down the vitiated vata dosha and nourishes the guna of kapha. Agnimandya is the main cause for the vatavyadhi. Agnimandya become corrected with the aid of using the dipan-pachan dravyas shunthi, ajawayan and shatapushpa. They have been additionally acted as vatanulomaka, vatashamaka and vedanasthapaka. In apabahuka, dhatukshaya rodhaka, dhatuvaradhaka, daurbalyanashaka chikitsa become important as mamsa and asthi dhatu kshaya have been located with generalized weak spot in dhatu, sandhis etc. The herbal drugs like ashwagandha, shatavari, guduchi, guggul, vriddhadaru, babbul, hapusha and goghrita have been act as balya, rasayan, vayasthapak which may be very important in vatavyadhi (apabahuk). In apabahuk vataprakopa, dhatukshinata, dhatu rukshata, parushata, asthidhatukshaya normally founds. The contents of trayodashang guggulu have been particularly guru, snigdha gunatmak, madhur rasa, madhur vipaki and ushna viryatmak in its properties (9), which corrects the above-referred to signs and symptoms.

\section{Rasna panchak kashaya}

The ingredients of the rasnapanchaka kwatha include rasna and erandamula are best drugs in vatavyadhi. Guduchi, devadaru and shunthi show its action on asthi and amjja dhatu (10). Thus, rasnapanchaka kwath has agnideepan, vatashamak, anulomana, shulahara, shothahara and rasayana qualities, which results in established order of equilibrium state of doshas \& as a consequence liberating the symptoms of apabahuk.

\section{Patra pinda sweda}

In nirgundi patra pinda sweda, nirgundi, eranda, rasna, arkapatra, haridra, nimbu swaras, narikela and tila taila have been used. Nirgundi have kapha-vata shamaka, rasayana, analgesic and antiinflammatory properties. Tila taila had snehana, sandhaniya, and rasayana properties. Before patra pinda sweda, abhyanga was done and which helps in subsides the vitiated vata-kpha dosha. The properties of abhyanga are kledakara, jarahara, (8) paushtikara, and kapha-vata nirodhana. The sneha dravyas used for abhyanga penetrates the deeper tissues like masa, meda, asthi and majja dhatu and so on. Abhyanga increases the muscle strength, helps in reducing the stiffness of muscle, increases blood flow to parts and helps in metabolism. After abhyanga, patra pinda sweda become implemented to the affected part of the body, which become kapha-vatanirodhana, agnideepaka, sandhichestakara, and srotosuddhikara. It reduces the stambha, shula(pain) and relaxes the muscles. Svedan increases the blood flow to the tissue and which helps in absorption of the sneha through the skin. Like this svedan helps in relieving stiffness and pain. Sanga is the type of srotodusti occurs in apabahuk and to resolves the sanga. Patra pinda sveda plays an important role and the properties of drugs like analgesic, antiinflammatory helps to get rid up of disease and helps in brings homeostasis of the doshas in the affected part and also in the body (11).

\section{Matra basti}

It is continually relevant to the person who is suffering from vataja vyadhi. It promotes strength, without calling for any strict routine of diet, and additionally reasons proper evacuation of Mala and Mutra. It plays the characteristic of brimhana and also cures Vatavyadhi (12). Virya of Basti is conveyed to Apana after which to samana vata, which can also additionally modify the characteristic of Agni (13). It then is going to udana, vyana, and prana, hence presenting its efficacy everywhere in the body. At the same time, Basti pacifies vata, restores the disturbed kapha and pitta at their authentic seats and hence enables in breaking the pathogenesis.

\section{Greeva basti}

It is one of the bahir-parimarjana chikitsa via which outside snehana and swedana is done. snehana and swedana are cautioned for the remedy of vata disorders (14). greeva basti presents neighborhood snehana and swedana on the affected vicinity. snehana presents nourishment to the dhatu and swedana relaxes the muscle groups, increase the blood flow and decreases the inflammations. swedana having ushna guna reduces the kleda of the affected vicinity inflicting comfort withinside the gaurava and stambha. skin is one of the sensitive organs of the body and medicines applied to skin are absorbed inner because of its permeability (15). Kottamchukkadi tail have antiinflammatory, analgesic and anti- arthritis properties. Kottamchikkadi tail via greeva basti facilitates withinside the rest of muscle groups, reduces ache and inflammations via its vatahara properties. luke warmth of the oil acts as neighborhood swedana and facilitates to lessen pressure of the muscle groups and will increase the blood flow. snigdha and ushna guna facilitates to counter act the ruksha and sheeta guna of vata. hence, kottamchukkadi tail in conjunction with the action of greeva basti facilitates to lessen the signs and symptoms like pain, stiffness and will increase the movements of the joints. 


\section{Conclusion}

In this clinical study, improvement was observed in the patient who was suffering from the frozen shoulder. Subjective and objective parameters have shown significant improvement with ayurvedic management which includes kostashodan, patrapinda sweda, sarvanga abhyanga and oral herbal medicines.

\section{References}

1. Sharma Anantaram. Sushruta Samhita of Acharya Sushruta, 1st edition. Varanasi; Choukhamba Surabharati prakashana; 2012, p470-600.

2. Acharaya Jadavji Trikamji Susruta. Sushruta Samhita of Acharya Sushruta, 2 ${ }^{\mathrm{ND}}$ edition. Varanasi; Choukhamba Orientalia; 2003.p824, p597.

3. Sharma Anantaram. Sushruta Samhita of Acharya Sushruta, 1st edition. Varanasi; Choukhamba Surabharati prakashana; 2012. p97, p610

4. Bramhanand.T. Madhava nidan of madhavakar with madhukosha commentary; $1^{\text {st }}$ edition. Varanasi: Chaukhamba Surabharati prakashan; 1986. 22/65

5. Longo D, Fauci A, Kasper D, Hauser S, Jameson J, Loscalzo J. Harrison's Principles of Internal Medicine, 18th Edition. 18th ed. McGraw-Hill Education/Medical; 2012

6. Dalvi, A. S., \& Gandhi, A. S. (2019). Case StudyManagement of Avabahuka With Special Reference to Frozen Shoulder by Ayurvedic Medicine. International Journal of Research -Granthaalayah, 7(3), 116-119.

7. Joydip Tripathi et al: A Clinical Study on The Role of Nasya Karma in The Management of Avabahuka
(Frozen Shoulder) With Vatada Taila. International Ayurvedic Medical Journal \{online\} 2018

8. Vermeulen HM, Stokdij KM. Measurement of three-dimensional shoulder movement patterns with an electromagnetic tracking device in patients with frozen shoulder. Ann Rheum D Sn. 2002; 61:115120.

9. S. RH, S SR. Evaluation of efficacy of Trayodashang guggulu in management of Cervical spondylosis (Manyagata vata. J Biol Sci Opin. 2013;1(2):65-69.

10. Anna Moreshwar kunthe. Ashtangahrudaya of Vagabhata, 1st Edition. Varanasi; Chukhambha prakashan; 2010.p16.

11. Joshi A, Mehta CS, Dave AR, Shukla VD. Clinical effect of Nirgundi Patra pinda sweda and Ashwagandhadi Guggulu Yoga in the management of Sandhigata Vata (Osteoarthritis). Ayu. 2011;32(2):207-212.

12. Charakabala D, Shastri RD, Acharya YT. Charaka Samhita of Agnivesha. 5th ed. Varanasi: Chaukhambha Sanskrit series; 2001.; p. 701.

13. Shastri L. Ashtanga Samgraha with Sarvanga Sundari Vyakhya; 1st ed. Baidyanath Ayurved Bhavan Pvt. Ltd; 1989. p. 1105.

14. Harish Chandra Singh Kushwaha. Charaka Samhita of Agnivesha; 1st ed. Varanasi; Chaukhambha Sanskrit Sansthan; 2018; 2.

15. https://www.researchgate.net/publication/ 333916870 potential benefits of greeva basti in cervical_spondylosis_-a_case_report $\overline{\#} 1$ date $\bar{d}$ 19-04-20̄ 1 time 10.00 IST. 